\title{
The influence of mountain temperate forests on the hydrology in northeast China ${ }^{1}$
}

\author{
by Xiaohua $\mathrm{Wei}^{2}$, Xiaofeng Zhou ${ }^{3}$ and Chuankuan Wang ${ }^{4}$
}

Presented is a review of results from long-term hydrological studies at the Mao-Er-Shan ecological station in northeast China. In comparison to harvested watersheds in northeast China, unlogged temperate forests reduced peak discharge and surface flows at all observed watershed scales ( $2 \mathrm{~m}^{2}$ to $>10000$ ha). However, no consistent patterns on low flows and annual mean flows were observed. The reason for the inconsistency is unclear and may be due to the utilization of different methodologies applied at the various spatial scales. We also found that stemflow is an important mechanism for Mongolian oak (Quercus mongolica Fisch) to adapt to nutrientpoor and dry soils. These results are important for developing forest management strategies and reforestation programs in northeast China.

Keywords: Temperate forest, hydrology, stemflow, interception, streamflow, evapotranspiration

Cet article est une revue des résultats des études hydrologiques à long terme de la station écologique Mao-Er-Shan située dans le nord-est de la Chine. Par comparaison avec les bassins versants récoltés dans le nord-est de la Chine, les décharges de pointe et l'écoulement de surface des forêts tempérées non exploitées sont réduits pour toutes les échelles de bassins observés $\left(2 \mathrm{~m}^{2}\right.$ à plus de 10000 ha). Cependant, aucun patron constant d'écoulement faible et d'écoulement annuel moyen n'a été observé. La raison de cette inconsistance est imprécise et pourrait découler de l'utilisation de différentes méthodologies appliquées à diverses échelles spatiales. Nous avons également constaté que l'écoulement sur le tronc représente un important mécanisme d'adaptation pour le chêne de Mongolie (Quercus mongolica Fisch) sur les sols pauvres en éléments nutritifs et secs. Ces résultats sont importants pour le développement de stratégies d'aménagement forestier et de programmes de reboisement pour le nord-est de la Chine.

Mots-clés : Forêts tempérées, hydrologie, écoulement sur le tronc, interception, écoulement des eaux, évapotranspiration

\section{Introduction}

The temperate forests in northeast China support thousands of forestry-dependent communities (Wang 1980). Over-exploitation of forest resources in past decades has caused serious concerns over negative impacts on the water resource, biodiversity, soil erosion, wildlife habitat and community stability. One key concern is the impact of forestry practices on hydrology, par-

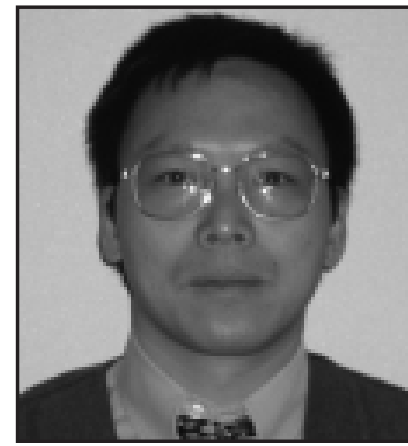

Xiaohua Wei ticularly the effect of forest harvesting on water quality and quantity (Zhou et al. 1994). However, lack of data greatly limits our ability to design reforestation programs and watershed rehabilitation projects.

The nationwide debate in the early 1980s over the importance of forests in environmental protection initiated forest hydrological studies in China (Zhou et al. 1994). Scientists from forestry and environmental disciplines suggested that forests play a vital role in water cycling, and argued for reforestation programs to

${ }^{1}$ Paper presented at "Mountain Forests: Conservation and Management," IUFRO Silviculture Conference, Vernon, British Columbia, Canada, July 28-August $1,2002$.

${ }^{2}$ Earth and Environmental Science Department, Okanagan University College, 3333 College Way, Kelowna, BC V1V 1V7. E-mail: awei@ ouc.bc.ca ${ }^{3}$ College of Forest Resource and Environment, Northeast Forestry University, Harbin, 150040, China.

${ }^{4}$ Department of Forest Ecology and Management, University of Wisconsin, Madison, USA.

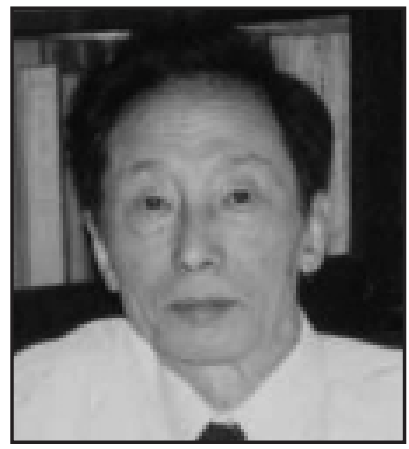

Xiaofeng Zhou

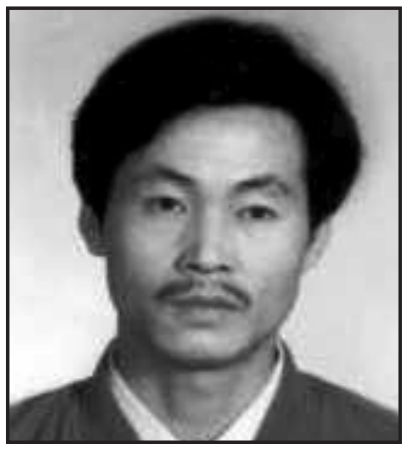

Chuankuan Wang restore forest coverage to large areas of land, and for control of logging as essential means for regulating streamflow and controlling soil erosion. Other scientists, mainly from the fields of geography, climatology and agriculture, considered forests to play a more limited role on water budgets. Without sound data, the debate was fruitless (Zhou et al. 1994). However, the debate did launch a milestone research program. Fourteen long-term ecological stations, covering various vegetation types, have been established since the middle of 1980s. We will summarize the results from the most intensive hydrological studies in the country at Mao-Er-Shan ecological station that represents the temperate forests of northeast China.

\section{Study Area and Methods}

The Mao-Er-Shan ecological station is located in Heilongiiang province, northeast China $\left(\mathrm{N} 45^{\circ} 20^{\prime}-25^{\prime}, \mathrm{E} 127^{\circ} 30^{\prime}-34^{\prime}\right)$. The climate is continental temperate, with a long cold winter and a short warm summer. The lowest temperature recorded 
in winter is $-43.9^{\circ} \mathrm{C}$, and the highest in summer is $38^{\circ} \mathrm{C}$. The total precipitation is about $600-700 \mathrm{~mm}$, of which $50-80 \%$ occurs as rainfall from May to September. There are generally two peaks in a typical streamflow hydrograph, occurring in spring as snowmelt flow and in summer as rainfall streamflow. The summer rainfall-driven streamflow accounts for 50-80\% of annual runoff while snowmelt streamflow and winter base flow total about 20-30\%. The topography in the study area is hilly, with the maximum elevation of $707 \mathrm{~m}$.

Climax vegetation consists of a broad-leave mixture dominated by Korean pine (Pinus koraiensis Sieb \& Zucc.). Other important tree species including Mongolian oak (Quercus mongolica Fisch), Manchurian ash (Fraxinus mandshurica Rupr.), Dahurian larch (Larix gmelinii Kuzeneva) and white birch (Betula platyphylla Sukatschev) are common in the naturally disturbed (wildfire) or harvested sites. The oak forests normally occur at the upper elevations where other tree species hardly survive due to limited moisture and nutrients in that environment. Plantations of Korean pine, Scots pine (Pinus sylvestris L.) and larch are common in the study area.

\section{Rainfall interception}

Throughfall $(\mathrm{T})$ was collected using five $4 \times 0.2 \times 0.2-\mathrm{m}$ plastic troughs randomly located underneath the canopy of each selected forest type (oak, birch, pine and larch). Rainfall (R) was measured using standard rain gauges in adjacent openings. At least 15 trees of various diameter classes in each forest type were selected for measurement of stemflow (S). Stemflow was collected using an open PVC tube wrapped around the stem and then inserted into a container. Snow interception was not studied in these forests. The canopy rainfall interception (I) was calculated as the residual:

$$
\mathrm{I}=\mathrm{R}-\mathrm{T}-\mathrm{S}
$$

\section{Evapotranspiration}

The energy balance method was used to estimate evapotranspiration in some of the forest types in northeast China. This approach has been applied in China and other countries to estimate evapotranspiration (He and Liu 1980). In order to apply the energy method a wooden tower (about 30 metres in height) was installed in each forest type (oak and birch forests). The tower was evenly divided into five layers with the highest layer situated above the canopy layer and the lowest layer situated at the ground surface with the three remaining layers situated in between. Data collected at each layer included radiation, humidity, temperature, wind and evaporation at an hourly interval for the selected dates of the growing seasons.

\section{Runoff and streamflow}

Three different methods were used to examine yields of runoff and streamflow at various watershed scales. Small closed plots $\left(1 \times 2 \mathrm{~m}=2 \mathrm{~m}^{2}\right)$ with and without trees were used to measure surface runoff, interflow, and assumed deep seepage on the surface of base rock (Wei and Zhou 1991). Four small plots were randomly assigned in each of oak and birch forest types. Paired watershed comparisons were used to examine the effect of forest harvesting on streamflow yield and nutrient output in small watersheds. Three gauged watersheds were established in 1984, namely the control (147 ha), treatment 1 (16 ha), and treatment 2 (24 ha). After four years of calibration mea-
Table 1. Canopy rainfall interception during the growing season (May to September) for different stands (1987-1989)

\begin{tabular}{lcc}
\hline $\begin{array}{l}\text { Forest } \\
\text { Type }\end{array}$ & $\begin{array}{c}\text { Canopy Coverage } \\
(\boldsymbol{\%})\end{array}$ & $\begin{array}{c}\text { Interception Rate } \\
(\boldsymbol{\%} \text { of total rainfall) }\end{array}$ \\
\hline Oak & 95 & 20.0 \\
Oak & 60 & 15.2 \\
Birch & $90-95$ & 25.9 \\
Pine & $90-95$ & 25.3 \\
Larch & $90-95$ & 23.0
\end{tabular}

surements, the treatment watersheds were strip-cut with $50 \%$ basal area removed in the winter of $1987 / 88$. Hydrological variables were monitored until 1990, at which point monitoring ceased since the weirs were damaged in the winter by frozen conditions.

For catchments ranging from 200-10 000 ha in the region, streamflow data in 1957-1984 was obtained from the four gauged watersheds located in the Binxian region. A regression analysis was conducted to test relationships between selected hydrological variables (annual mean, peak and low flows) and forest coverage rates. For the catchments larger than 10000 ha (20 watersheds) in the region, streamflow, precipitation, topography and forest data were obtained from forest resources, hydrology, and meteorology departments of Heilongjiang province. A multi-variable regression was conducted to examine relationships between these data items and streamflow (Cao et al. 1994). Based on the constructed multi-variable regression, the influences of forest coverage on streamflow variables were quantified.

\section{Results and Discussion \\ Rainfall interception}

Canopy rainfall interception accounted for $15-26 \%$ of total rainfall during the growing season in the mature temperate forests (Table 1). The forest coverage rate is an important factor influencing the interception. When the forest coverage rate in the oak forest decreased from $95 \%$ to $60 \%$ after spacing, the interception rate dropped from $20 \%$ to $15.2 \%$ (Table 1). Forest canopy interception was also related to rainfall amount and intensity based on our studies. The interception rates were greater $(>50 \%)$ when rainfall amounts were less than $5 \mathrm{~mm}$ and rainfall intensities were less than $10 \mathrm{~mm} \cdot \mathrm{hr}^{-1}$. The interception rates generally decreased with increases in rainfall amounts and intensities. The probable explanation for this decrease may be the limited water-holding capacity of the canopies when the canopies were wet.

Our results are similar to the measured interception loss in pine (Pinus pseudostrobus Lindl.) (19.2\%), oak (Quercus spp.) (13.6\%) and pine-oak (23\%) natural forest canopies in northeastern Mexico reported by Silva and Rodriguez (2001). According to Spittlehouse (1998), numerous studies have shown that up to $30 \%$ of the annual rainfall does not reach the ground in many types of coniferous forests.

The ecological role of canopy interception should be noted. Part of the intercepted water evaporates during and after rainfall events while the remaining rainfall can become stemflow. Canopy interception may reduce the kinetic energy of rainfall drops, which reduces surface and consequently soil erosion, particularly when there is no or limited under-story vegetation (Zhou et al. 2002). In addition, forest canopies redistribute pathways of rainfall. 


\begin{tabular}{lc}
\hline Table 2. Stemflow in various forest types in northeast China \\
\hline Forest Type & Stemflow Rate (\% of rainfall) \\
\hline Old Growth: pine mixture & 0.7 \\
Secondary: birch & 4.6 \\
ash & 8.4 \\
oak & 15.5 \\
Plantation: Korean pine & 3.8 \\
Scots pine & 2.6 \\
larch & 1.7 \\
\hline
\end{tabular}

\section{Stemflow}

Stemflow as a percentage of total rainfall varied greatly between forest types in northeast China (Table 2). The oak forests had the highest amount of stemflow (15.5\%), with Korean pine old-growth forests having the lowest $(<1 \%)$. The highest amount of stemflow in oak forests may be due to their large thick leaves and rigid petioles that facilitate interception and channelling of water to form stemflow. This indicates that tree leaf morphology is an important factor influencing stemflow. Great variations in stemflow between tree species have also been shown in other studies (Dong et al. 1994, Tian et al. 1994, Spittlehouse 1998).

The importance of stemflow is commonly neglected in most forest ecosystem studies largely because of its relatively small amount (Wei 1984). However, stemflow may be crucial for Mongolian oak to grow in the harsh micro-environment of this region. Oak forests normally occur on hilltops where other species hardly survive due to dry and nutrient-poor soils. Wei and Zhou (1991) reported that the nutrient contents (N, P, K) were significantly greater in stemflow than in rainfall and throughfall. These results suggest that the stemflow of oak might be one of the mechanisms for Mongolian oak to adapt to nutrient-poor and dry soils.

\section{Evapotranspiration}

Evapotranspiration was the largest component of the water budget in these temperate forests, ranging from $77.5 \%$ of total rainfall (660 mm in 1988-1989) for oak stands to $87.0 \%$ for white birch stands during the growing season. The relatively high evapotranspiration in these two types of forests may be attributed to the coincidence of high temperature with high rainfall (water availability) during the growing season in northeast China. It is expected that the percentage of evapotranspiration would be less if estimated on an annual basis because of the relatively higher proportion of precipitation that falls as snow and lower evapotranspiration in the winter. But winter evapotranspiration has not yet been measured.

Numerous studies from other forest types in China have also shown that evapotranspiration is the most important compo- nent of the water budget. For example, annual evapotranspiration from a mature Chinese fir forest in southern China (Tian et al. 1994) and an armand pine stand in western China (Lei et al. 1994) was about $72 \%$ and $58 \%$ of total precipitation, respectively.

\section{Runoff and streamflow}

When watersheds were less than 10000 ha, forests (or harvesting) reduced (or increased) annual, peak and surface flows, which is consistent with other studies in China (Zhou et al. 1994). The plausible reason for this may be the higher evapotranspiration rate in these forested watersheds. However, when watersheds were larger than 10000 ha, forests tend to increase annual mean and low flows, which is supported by two Russian studies in the far-east region (Cao et al. 1994). We suggest the following reasons for this apparent contradiction: (1) As watershed scales increase landscape heterogeneity (wetlands, ponds etc.) increases, which could act as buffers to streamflow changes in response to forest changes. A quicker response of streamflow is generally expected from forest cover change in smaller watersheds. (2) Inconsistent methods employed in the studies summarized make comparisons difficult. (3) Specific characteristics of watersheds (climate, geology, soil, vegetation, and land uses) may obscure the effect of forest coverage on streamflow. This indicates that impacts of forests on hydrology are site-specific and scale-specific. The paucity of data impedes our understanding of the uncertainties in these studies, and more research is needed to study scale issues of forest hydrology and other important topics such as groundwater, snow hydrology and climate change impacts in northeast China.

\section{Summary}

Forestry is an important industry sector in northeast China, primarily due to its significance of forest resources in China. However, the region suffers greatly from frequent floods due to loss of watershed functions as a result of the large-scale deforestation, urbanization and land use competition. Hydrological studies are important for supporting environment protection and economic development in northeast China. These studies provide strategic information for determining what percentage of forest land in the region is required in order to protect water resources and support economic development. These studies also provide important information that supports operational practices such as forest regeneration programs, watershed restoration programs and best forest management strategies.

Regardless of watershed size, forests play an important, positive role in reducing surface runoff and peak flows. Soil erosion and flood frequency in forested ecosystems would be expected to be less than in harvested ecosystems because of

Table 3. Impacts of temperate forests on hydrological variables estimated from different approaches at various scales

\begin{tabular}{lccccc}
\hline & \multicolumn{5}{c}{ Impacts of forests on hydrological variables } \\
\cline { 2 - 5 } Approaches & annual mean flow & peak flow & low flow & surface flow & Data source \\
\hline Small runoff plots $\left(2 \mathrm{~m}^{2}\right)$ & $\downarrow$ & $\downarrow$ & $\mathrm{n} . \mathrm{m}^{*}$ & $\downarrow$ & Wei and Zhou 1991 \\
Paired watersheds $(\mathrm{small}, 20-200 \mathrm{ha})$ & $\downarrow$ & $\downarrow$ & $\mathrm{n} . \mathrm{m}$ & $\downarrow$ & Wang and Zhou 1994 \\
Regression (medium, 200-10 000 ha) & $\downarrow$ & $\downarrow$ & $\downarrow$ & $\downarrow$ & Zhou et al. 1994 \\
Regresson (large, $>10000 \mathrm{ha})$ & $\uparrow$ & $\downarrow$ & $\uparrow$ & n.m & Cao et al. 1994 \\
\hline
\end{tabular}

*not measured. 
reduced surface and peak flows. Forest impacts on hydrology are site-specific and scale-specific, and caution must be exercised when extrapolating results from one scale to others.

\section{References (all in Chinese except annotated)}

Cao, Y., Q. Li, T. Cai and Y. Shen. 1994. The effects of forest coverage on river flow in the Songhua watersheds. In X. Zhou (ed.). Studies on Forest Ecosystems. pp. 396-402. Northeast Forestry University Press, Harbin.

Dong, S., J. Guo and R. Man. 1994. Throughfall, stemflow and crown interception in a Pinus tabulaeformis plantation in North China. In X. Zhou (ed.). Studies on Forest Ecosystems. pp. 261-267. Northeast Forestry University Press, Harbin, China.

He, Q. T. and Z. S. Liu. 1980. Radiation and heat balance in forests. Forest Science 16(1).

Lei, R., Y. Zhang and K. Dang. 1994. A study on hydrological effects of forest in the Qinling Mountains Forest Region. In X. Zhou (ed.). Studies on Forest Ecosystems. pp. 223-234. Northeast Forestry University Press, Harbin, China.

Silva, I.C. and H.G. Rodriguez. 2001. Interception loss, throughfall and stemflow chemistry in pine and oak forests in northeastern Mexico. Tree physiology 21: 1009-1013. (English)

Spittlehouse, D. 1998. Rainfall interception in young and mature coastal conifer forests. In Proceedings, Mountain to Sea: Human interaction with the hydrological cycle. Canadian Water Resource Association 51st National Conference in Victoria, BC, June 10-12, 1998. pp. 40-44. (English)
Tian, D., L. Sheng, B. He and H. Xu. 1994. A study on hydrological effect of artificial disturbance in a Chinese fir plantation ecosystem. In X. Zhou (ed.). Studies on Forest Ecosystems. pp. 384-393. Northeast Forestry University Press, Harbin, China.

Wang, C. and X. Zhou. 1994. Effects of strip cutting on streamflow in temperate forest ecosystems. In X. Zhou (ed.). Studies on Forest Ecosystems. pp. 373-379. Northeast Forestry University Press, Harbin, China.

Wang, Z. 1980. Forests and water balance. Terrestrial Ecology 11: 23-34.

Wei, X. 1984. Rainfall canopy distribution and rainfall chemistry in the northeast temperate forests. Master degree thesis. Northeast Forestry University. Harbin, China

Wei, X. and X. Zhou. 1991. Hydrological characteristics of oak forests. In X. Zhou (ed.). Studies on Forest Ecosystems. pp. 332-345. Northeast Forestry University Press, Harbin.

Zhou, G. Y., X. Wei and J. Yan. 2002. Impacts of eucalyptus (Eucalyptus exserta) plantation on sediment yield in Guangdong Province, Southern China-a kinetic energy approach. Catena 49: 231-251 (English).

Zhou, X. Q. Li and Y. Jin. 1994. Studies on forest hydrological cycling. In X. Zhou (ed.). Studies on Forest Ecosystems. pp.317-331. Northeast Forestry University Press, Harbin, China. 